\title{
Water intake behavior of broiler chickens exposed to heat stress and drinking from bell or and nipple drinkers
}

-Author(s)
Bruno LDG 1
Maiorka A ${ }^{2}$
Macari M 3
Furlan RL
Givisiez PEN ${ }^{4}$
1 Centro de Ciências Agrárias - UNIOESTE.
Campus de Marechal Cândido Rondon.
2 Departamento de Zootecnia. Universidade
Federal do Paraná.
3 Departamento de Morfologia e Fisiologia
Animal. Faculdade de Ciências Agrárias
e Veterinárias - UNESP. Campus de
Jaboticabal.
4 Departamento de Zootecnia. Centro de
Ciências Agrárias. Campus III. Universidade
Federal da Paraíba.

\section{mail Adress}

\section{LDG Bruno}

Centro de Ciências Agrárias - UNIOESTE

Campus de Marechal Cândido Rondon

Rua Pernambuco, 1777

85.960-000. Marechal Cândido Rondon,

Paraná, Brazil.

Phone number: +55 4532847871

Fax number: +55 4532847879

E-mail: luis.bruno@unioeste.br

\section{-Keywords}

Behavior, broilers, ingestion pattern, water.

\begin{abstract}
The aspects involved in broiler water intake are not well known, despite the importance of water in animal nutrition and physiology. Water intake behavior should be taken into account when deciding on different types of drinkers. Bell and nipple drinkers are the most commonly used in commercial broiler production. Broilers were housed in cages equipped with two different drinker types and raised at two different environmental temperatures ( 25 and $34{ }^{\circ} \mathrm{C}$ ) to evaluate water intake behavior and volume. Broiler water intake behavior was influenced by drinker type. Birds visited bell drinkers less often, but presented higher total water intake per visit to the drinker as compared to those drinking from nipple drinkers. The results of this study suggest that both broilers drinking behavior and water intake volume should be taken into account when deciding on drinker type to equip broiler houses.
\end{abstract}

\section{INTRODUCTION}

Water is not only one of the most important nutrients in animal nutrition, but also plays an essential physiological role related to the thermal homeostasis of birds and other animals, especially during heat stress. Leeson \& Summers (1991) and Lott (1991) reported that broilers submitted to acute heat stress have higher water intake. Water intake increases in order to maintain thermoregulatory balance (Bruno \& Macari, 2002), as heat stress induces high water loss through the respiratory tract as a means to achieve efficient thermoregulation through evaporative cooling. In critical heat stress situations water loss may cause marked changes in the thermoregulatory balance of poultry (Belay et al., 1993) and may result in death. Therefore, in addition to its nutritional role, water plays is more important for thermoregulation in modern broiler chickens as compared to other animal species (Bruno \& Macari, 2002), especially under hot conditions.

Considering the importance of water in the physiology of modern broilers, the poultry industry has tried to maximize the efficiency of water utilization introducing modifications in the design of water equipment, including drinkers. An example was the development of nipple drinkers. Such drinkers present some advantages as compared to bell-shaped hanging drinkers, which require less labor, waste less water and improves health aspects (Macari, 1996).

Although no effects of different drinker types (bell drinkers vs. nipple drinkers) used during the growout have been reported on broiler growth pattern (Vest, 1986; Fernandes et al., 2002), broilers submitted to early water deprivation present inadequate development of the intestinal mucosa (Maiorka et al., 2003). Therefore, drinkers that enable higher accessibility to water should be used, especially at high environmental 
temperatures (Silva et al., 2005). However, current broiler rearing management practices have been based on empiric knowledge on water intake behavior, and more precise information is needed.

Broiler water intake is directly related to many factors, including diet composition (Belay \& Teeter, 1993) and water quality (Barton, 1996; Grizzle et al., 1997). Nevertheless, one of the most important factors influencing broiler water intake pattern is environmental temperature. May \& Lott (1992) reported that broilers submitted to cyclic temperatures developed different patterns of water intake, and different acclimation temperatures may be responsible for the development of different water intake and excretion capacities to maintain hydro-electrolytic balance (Wideman et al., 1994). Moreover, in some situations, the type of drinker influenced water temperature (Klosowki et al., 2004). Thus, information on water consumption and better knowledge of the behavioral aspects involved in water intake are extremely important to the understanding of behavioral processes involved in water intake and to provide broiler thermoregulation needs.

The objective of this study was to evaluate the effects of bell and nipple drinkers on water intake behavior of broiler chickens submitted to heat stress.

\section{MATERIAL AND METHODS}

Thirty-two male Cobb-500 ${ }^{\circledR}$ broilers were reared in individual battery cages from one to 49 days of age in an environmentally-controlled poultry house (temperature and humidity). Temperature was kept at $35^{\circ} \mathrm{C}$ from one to four days of age $(\mathrm{d}), 32^{\circ} \mathrm{C}$ until day seven and then reduced $2^{\circ} \mathrm{C}$ weekly until $49 \mathrm{~d}$. Humidity levels were maintained at approximately $65 \%$ during the whole experimental period, according to temperature schedule and bird age. Broilers were fed diets formulated to supply the requirements recommended by NRC (1994) in the different rearing phases. Chick drinkers and trays were used until four days of age, and standard feeders and nipple or bell drinkers were used from then on. At $7,14,21,28,35,42$ and 49 days of age, all cages with broilers were transferred from the poultry house to the climatic chambers of the Department of Animal Morphology and Physiology (UNESP-Jaboticabal, Brazil) for a period of 1 hour before data collection. The climatic chambers were located very close from the poultry house, so the time to transport the birds was very short and insignificant.

Birds were distributed according to a $2 \times 2 \times 7$ factorial design (temperature $x$ drinker type $x$ age), with four experimental groups of eight birds per treatment: group 1 was kept at $25{ }^{\circ} \mathrm{C}$ and provided with a bell drinker; group 2 was kept at $34{ }^{\circ} \mathrm{C}$ provided with a bell drinker; group 3 was kept at 25 ${ }^{\circ} \mathrm{C}$ provided with a nipple drinker, and finally group 4 was kept at $34{ }^{\circ} \mathrm{C}$ provided with a nipple drinker. So, the birds were placed at $25{ }^{\circ} \mathrm{C}$ and $34{ }^{\circ} \mathrm{C}$ just for data collection. Birds were deprived of water for two hours before data collection in order to assure water intake and thorough evaluation of water intake behavior by broilers during the first ten minutes of free access to water. An important fact is that water temperature was not controlled, varying according environmental temperature to reproduce commercial rearing conditions. Nipple drinker height was adjusted according to Lott et al. (2001): nipple drinkers were set at a height that, when broilers drank, they extended their neck, and water dripped at the tip of the beak, activating the nipples by pressing the pin upwards. We believe that this height setting was similar those adopted as a normal management technique. We adopted nipples with low flow rates (approximately $0.6 \mathrm{~mL} / \mathrm{s})$.

The following conditions were established for data collection: each broiler had individual access to drinkers, which made data collection easy and avoided problems related to pecking order, which might have influenced or impaired data collection. In addition, birds had no contact with the researcher both during water fasting and during the period of water supply and ingestion, i.e., birds were monitored through a window in order to avoid any possible influence of the observer on the normal behavior of broilers. Finally, only one person evaluated the water intake behavior of birds throughout the experimental period.

The number of times that birds ingested water was recorded during the ten-minute interval (frequency of access to drinker, FVD) as well as the number of visits at two-minute intervals. Since both bell and nipple drinkers were connected to reservoirs containing known volumes of water, after ten minutes of bird free access to water, water volume remaining in the reservoirs was measured and total water intake in ten minutes (TWI, $\mathrm{mL}$ ) was calculated as the difference between the initial and final water volume. Water intake per access to the drinker (WIA, $\mathrm{mL} /$ visit) was obtained by dividing the total ingested water by the frequency of access to drinkers.

Data were analyzed according to a completely randomized $2 \times 2 \times 7$ factorial design (bell or nipple drinkers; 25 or $34^{\circ} \mathrm{C}$; ages and 7 broiler ages) with 8 
replicates (individual birds) per treatment. Analysis of variance was performed using GLM procedure of SAS software package (2000) and means were compared using the test of Tukey ( $5 \%)$.

\section{RESULTS AND DISCUSSION}

Literature usually provides information on the effect of drinker type on bird performance, but not on the behavior or patterns of water intake by broiler chickens. Considering that water is one of the most important nutrients in animal nutrition, any aspect involved in its relationship with broiler production is very important both from the physiological and the behavioral perspectives.

The results obtained in the present study showed differences between the utilization of bell and nipple drinkers by broilers as a function of the type of drinker, environmental temperature and broiler age.

The frequency of visits to the drinker ( $F A D$, number of visits), total water intake $(\mathrm{mL})$ and water intake per visit ( $\mathrm{mL} /$ visit) are presented in Table 1 according to the type of drinker, environmental temperature and bird age. Both drinker type and temperature affected $(p<0.01)$ the evaluated parameters. The frequency of visits to drinkers during the ten-minute interval of observation was higher for nipple drinkers (156.16 times) as compared to bell drinkers (35.67 times) or 4.38 times more visits to nipple drinkers. Relative to environmental temperature, broilers reared at $25^{\circ} \mathrm{C}$ visited drinkers more often than broilers reared at 34 ${ }^{\circ} \mathrm{C}$ (102.16 vs. 89.67 times) or 1.13 times more visits. Finally, the frequency of visits to drinkers increased with bird age, as biologically and physiologically expected. According with this data, the mean value obtained for the frequency of visits to drinker during the experimental period was 35 visits to bell drinkers and 156 visits to nipples. Such marked difference may be associated with the nature of the drinker that is used and the easiness of water intake provided by each drinker, i.e., bell drinkers have higher water availability as compared to nipple drinkers. Birds seemed to discontinue drinking water as a result of the difficulty to ingest water from nipple drinkers: birds would stand up, come closer to the nipple, peck it and laid down again. This was most evident in birds reared at $34{ }^{\circ} \mathrm{C}$, probably due to heat stress and when FAD to the nipples at $25^{\circ} \mathrm{C}$ and $34{ }^{\circ} \mathrm{C}$ were compared. Therefore, the factors that possibly have a strong influence on water intake in the case of bell drinkers and, consequently, also determine the
Table 1 - Frequency of visits to drinker (FAD, number of visits during a ten-minute interval), total water intake (TWI, $\mathrm{mL}$ ) and water intake per access to the drinker (WIA, mL/visit) of broilers drinking from bell or nipple drinkers and reared at 25 or $34^{\circ} \mathrm{C}$ (period of observation $=10$ minutes).

\begin{tabular}{|c|c|c|c|}
\hline Treatment & $\begin{array}{c}\text { FAD } \\
\text { (number of visits) }\end{array}$ & $\begin{array}{l}\text { TWI } \\
(\mathrm{mL})\end{array}$ & $\begin{array}{c}\text { WIA } \\
\text { (mL/visit) }\end{array}$ \\
\hline \multicolumn{4}{|l|}{ Type of drinker } \\
\hline Bell & $35.67 \pm 1.60$ & $28.11 \pm 0.03$ & $0.86 \pm 1.50$ \\
\hline Nipple & $156.16 \pm 5.21$ & $3.72 \pm 0.0009$ & $0.024 \pm 0.16$ \\
\hline \multicolumn{4}{|l|}{ Temperature } \\
\hline $25^{\circ} \mathrm{C}$ & $102.16 \pm 8.70$ & $13.98 \pm 1.45$ & $0.405 \pm 0.04$ \\
\hline $34^{\circ} \mathrm{C}$ & $89.67 \pm 5.45$ & $17.85 \pm 1.74$ & $0.478 \pm 0.05$ \\
\hline \multicolumn{4}{|l|}{ Age } \\
\hline 7 days & $72.67 \pm 8.24$ & $7.54 \pm 1.16$ & $0.20 \pm 0.03$ \\
\hline 14 days & $74.83 \pm 10.02$ & $10.21 \pm 1.96$ & $0.32 \pm 0.06$ \\
\hline 21 days & $116.00 \pm 16.45$ & $13.56 \pm 2.06$ & $0.30 \pm 0.06$ \\
\hline 28 days & $97.24 \pm 13.09$ & $18.75 \pm 3.54$ & $0.51 \pm 0.09$ \\
\hline 35 days & $96.95 \pm 13.73$ & $17.67 \pm 2.93$ & $0.46 \pm 0.09$ \\
\hline 42 days & $101.15 \pm 13.32$ & $21.06 \pm 3.62$ & $0.60 \pm 0.10$ \\
\hline 49 days & $112.54 \pm 16.12$ & $22.62 \pm 3.74$ & $0.67 \pm 0.13$ \\
\hline \multicolumn{4}{|c|}{ Source of variation } \\
\hline Drinker (D) & $\star \star *$ & ** & $\star \star *$ \\
\hline Temperature $(T)$ & ** & $\star *$ & $\star *$ \\
\hline Age $(A)$ & ** & ** & ** \\
\hline $\mathrm{D} \times \mathrm{T}$ & $\star *$ & ** & ** \\
\hline$D \times A$ & ** & ** & ** \\
\hline$A \times T$ & NS & NS & $\star \star$ \\
\hline$D \times A \times T$ & NS & NS & ** \\
\hline C.V. (\%) & 31.31 & 50.91 & 31.96 \\
\hline
\end{tabular}

frequency of visits, are water availability at the drinker and the physical ability of broilers to drink water, either as a result of beak size or possible physical limitation related to crop size. During the experiment, it was observed that broilers using bell drinkers would stop visiting the drinker only when the crop was full and completely distended (particularly until 21 days of age). Another interesting fact was related to the use of nipple drinkers. In our experiment we observed waste of water and possible underutilization of the equipment. Broilers would come near the drinker and pushed the valve only partially. Even when the valve was completely pressed by one bird at a given time, pushing was fairly brief. We believe that this waste may be caused by fact that the beak and the valve did not properly fit, and consequently, the water coming out of the drinker was not ingested by the bird; rather, it would fall on the litter, increasing litter moisture. However, this is considered irrelevant under commercial conditions. Litter moisture determination was part of this study, but we observed that nipples tended to cause higher moisture in the litter under the drinkers. This problem was more frequently observed 
until birds were 28 days of age, when their beak was still small. After that, water loss decreased probably because the beak had already grown and fitted better the water valve. These observations corroborate the idea that drinking water through a nipple is not the natural drinking behavior of broilers, and therefore may cause some problems (Lott et al., 2001).

Total water intake $(T W I)$ was influenced $(p<0.01)$ by drinker type, environmental, temperature and broiler age. As expected, total water intake was 7.55 times higher in bell drinkers $(28.11 \mathrm{~mL})$ as compared to nipples $(3.72 \mathrm{~mL}$ ) during the observation period. Birds kept at $34{ }^{\circ} \mathrm{C}$ consumed $17.85 \mathrm{~mL}$ of water, whereas those kept at $25{ }^{\circ} \mathrm{C}$ drank $13.98 \mathrm{~mL}$ (a $3.87 \mathrm{~mL}$ difference), demonstrating the effect of temperature on water intake. Moreover, as previously found for FAD, TWI increased with bird age.

Water intake per access (WIA) results, as well as TWI, was influenced $(p<0.01)$ by type of drinker, environmental temperature and bird age. Considering the effects of type of drinker, birds drinking from bell drinkers presented 35.83 times higher WIA $(0.86 \mathrm{~mL})$ as compared to birds housed in cages with nipple drinkers $(0.024 \mathrm{~mL})$. As to environmental temperature birds kept at $25^{\circ} \mathrm{C}$ showed lower WIA as compared to birds housed at $34{ }^{\circ} \mathrm{C}(0.405 \mathrm{~mL}$ vs. $0.478 \mathrm{~mL})$. And, again, the effect of age was the same as that found for FAD and TWI.

Data show that water intake per visit to drinker was 35.83 times higher with bell drinker as compared to nipple drinkers, as expected. Intake per visit was $18 \%$ higher at $34{ }^{\circ} \mathrm{C}$ than at $25{ }^{\circ} \mathrm{C}$, demonstrating that temperature affects water intake behavior and the importance of providing adequate and efficient water supply for broilers.

The higher number of visits to the drinkers at $25^{\circ} \mathrm{C}$ as compared to $34{ }^{\circ} \mathrm{C}$ was surprising, as it is expected that water intake of broilers submitted to higher environmental temperatures should be higher to regulate physiological functions and body temperature. The higher number of visits at $25^{\circ} \mathrm{C}$ may be due to a possible anatomical limitation of broilers relative to crop capacity, that is, higher temperatures prevent the intake of a higher amount of water, whereas under commercial conditions, it may be more difficult to broilers approach the drinkers. A second factor is that the size of crop may not have allowed the ingestion of high amounts of water in each visit to drinker. Therefore, the birds have to visit the drinkers more frequently to compensate for this limitation when submitted to high temperatures. At $34{ }^{\circ} \mathrm{C}$, total water intake was a little higher for nipple drinkers as compared to bell drinkers, indicating a possible limitation of the use of this type of drinker at high environmental temperatures.

Table 1 also shows significant interactions $(p<0.01)$ between drinker type and age and between drinker type and environmental temperature for the three evaluated parameters, and between environmental temperature and age for water intake per event.

The frequency of visits to bell drinkers at $34^{\circ} \mathrm{C}$ was higher relative to $25^{\circ} \mathrm{C}$ (42 vs. 28). When bell drinkers were used, less water was ingested per visit, but total water intake was higher during the total period of observation. Surprisingly, it seems that heat stress induced by high environmental temperature did not induce a possible "optimization" of broiler behavior, that is, it would be expected that birds would ingest more water per visit to the drinker and visit the drinkers less often. This was more evident when the results of nipple drinkers were analyzed (Table 3).

Except for frequency of visits to nipple drinkers (176.74 vs. 136.13) and water intake per visit to bell drinkers (0.95 vs. $0.78 \mathrm{~mL}$ ), which were higher at 25 ${ }^{\circ} \mathrm{C}$ as compared to $34{ }^{\circ} \mathrm{C}$, the results of the interaction between environmental temperature and type of drinker (Table 2) show that the highest parameter values were usually obtained at $34{ }^{\circ} \mathrm{C}$. This could indicate that there is an anatomical or physiological

Table 2 - Effect of the interaction between type of drinker and environmental temperature on frequency of visits to drinker (FAD, number of visits during a ten-minute interval), total water intake (TWI, $\mathrm{mL}$ ) and water intake per access (WIA, mL/visit) during 10 minutes of observation (means standard error of mean).

\begin{tabular}{|c|c|c|c|}
\hline & \multirow{2}{*}{ Drinker type } & \multicolumn{2}{|c|}{ Temperature } \\
\hline & & $25^{\circ} \mathrm{C}$ & $34^{\circ} \mathrm{C}$ \\
\hline FAD & Bell & $28.06 \pm 2.14 \mathrm{Bb}$ & $42.44 \pm 2.57 \mathrm{Ba}$ \\
\hline (number of visits) & Nipple & $176.74 \pm 14.32 \mathrm{Aa}$ & $136.13 \pm 9.68 \mathrm{Ab}$ \\
\hline TWI & Bell & $24.60 \pm 1.98 \mathrm{Ab}$ & $31.48 \pm 2.64 \mathrm{Aa}$ \\
\hline$(\mathrm{mL})$ & Nippe & $3.48 \pm 0.20 \mathrm{Ba}$ & $3.93 \pm 0.12 \mathrm{Ba}$ \\
\hline WIA & Bell & $0.95 \pm 0.03 \mathrm{Aa}$ & $0.78 \pm 0.05 \mathrm{Ab}$ \\
\hline (mL/visit) & Nipple & $0.02 \pm 0.004 \mathrm{Bb}$ & $0.03 \pm 0.002 \mathrm{Ba}$ \\
\hline
\end{tabular}

$A, B$ - Means in the same column followed by different letters are significantly different $(p<0.01)$ by the test of Tukey. a,b - Means in the same row followed by different letters are significantly different $(p<0.01)$ by the test of Tukey. 
limitation that controls the water intake of broilers reared under similar conditions, and that this control is more important than type of drinker or environmental temperature. This control would be anatomically exerted by the proventriculus, and physiologically by environmental temperature in association with mechanisms that prevent water imbalance. This possible limitation account for the number of visits observed at $25^{\circ} \mathrm{C}$. Klosowski et al. (2004) found in a study with layers that the water temperature in nipple drinkers was higher as compared to continuous drinker system. Although water temperature in the drinkers was not measured in the present experiment, it may have been different between nipple and bell drinkers.

Table 3 shows the mean frequency of visits at two-minute intervals (total period of observation $=10 \mathrm{~min}$ ) of broilers using bell or nipple drinkers at environmental temperatures of $25^{\circ} \mathrm{C}$ or $34^{\circ} \mathrm{C}$, respectively. The frequency of visits to bell drinkers was higher in the beginning of water supply and decreased with time. Similar results were obtained with nipple drinkers, except that the frequency of visits to this type of drinker was much higher during the total period of observation. The results were similar at $25^{\circ} \mathrm{C}$ and 34 ${ }^{\circ} \mathrm{C}$ (Table 3).

As to the effect of age on the evaluated parameters, the observed pattern of water intake increase with age was expected. However, it must be stressed that broiler visits to drinkers were observed for 10 minutes, with data collected during this period. We observed that the main factor that interrupted water intake was associated with physical limitations (probably because birds became tired), which was more evident during the last three observations (35, 42 and 49 days of age). This could give the impression that those water intake volumes correspond to broilers' maximum capacity of water intake as a function of age, but this is not correct since we know that water intake increases with broiler age.

Physiologically, these results have important implications to broiler performance, because water is the most important nutrient for animal and human nutrition. Low water intake results in low food intake, reducing the availability of water and nutrients required by biochemical and physiological function that are essential for body homeastasis and growth. From the physiological point of view, less water is much more detrimental than its excess. Water loss is the main mechanism used by broilers for thermoregulation. With no access to water or only to low water levels, broilers are more sensitive to environmental temperature variations.
Table 3 - Frequency of visits to the drinker of broilers drinking from bell or nipple drinkers and reared at 25 or $34{ }^{\circ} \mathrm{C}$ (period of observation $=10$ minutes) .

\begin{tabular}{|c|c|c|c|c|c|}
\hline \multirow[b]{2}{*}{ Age } & \multirow[b]{2}{*}{ Intervals } & \multicolumn{2}{|c|}{$25^{\circ} \mathrm{C}$} & \multicolumn{2}{|c|}{$34^{\circ} \mathrm{C}$} \\
\hline & & $\begin{array}{c}\text { Bell } \\
\text { drinker }\end{array}$ & $\begin{array}{l}\text { Nipple } \\
\text { drinker }\end{array}$ & $\begin{array}{c}\text { Bell } \\
\text { drinker }\end{array}$ & $\begin{array}{c}\text { Nipple } \\
\text { drinker }\end{array}$ \\
\hline \multirow{5}{*}{7 days } & $0-2^{\prime}$ & 16.85 & 52.37 & 21.13 & 37.14 \\
\hline & $2-4^{\prime}$ & 7.96 & 28.32 & 8.59 & 24.29 \\
\hline & $4-6^{\prime}$ & 5.48 & 24.12 & 5.24 & 15.00 \\
\hline & $6-8^{\prime}$ & 3.87 & 20.14 & 1.65 & 3.71 \\
\hline & $8-10^{\prime}$ & 1.54 & 16.16 & 0.00 & 1.86 \\
\hline \multirow{5}{*}{14 days } & $0-2^{\prime}$ & 15.14 & 62.22 & 27.35 & 40.36 \\
\hline & $2-4^{\prime}$ & 5.80 & 30.66 & 10.63 & 22.16 \\
\hline & $4-6^{\prime}$ & 1.86 & 17.00 & 2.00 & 24.35 \\
\hline & $6-8^{\prime}$ & 0.43 & 6.45 & 0.00 & 18.58 \\
\hline & $8-10^{\prime}$ & 0.00 & 3.66 & 0.00 & 4.76 \\
\hline \multirow{5}{*}{21 days } & $0-2^{\prime}$ & 17.72 & 64.16 & 24.71 & 51.23 \\
\hline & $2-4^{\prime}$ & 6.71 & 62.83 & 17.29 & 36.12 \\
\hline & $4-6^{\prime}$ & 0.86 & 37.17 & 8.57 & 28.74 \\
\hline & $6-8^{\prime}$ & 0.00 & 35.52 & 0.14 & 25.65 \\
\hline & $8-10^{\prime}$ & 0.00 & 18.84 & 0.00 & 5.23 \\
\hline \multirow{5}{*}{28 days } & $0-2^{\prime}$ & 15.86 & 43.16 & 23.12 & 46.12 \\
\hline & $2-4^{\prime}$ & 4.57 & 31.12 & 15.51 & 39.58 \\
\hline & $4-6^{\prime}$ & 0.43 & 35.46 & 7.75 & 30.36 \\
\hline & $6-8^{\prime}$ & 0.00 & 26.25 & 4.00 & 16.16 \\
\hline & $8-10^{\prime}$ & 0.00 & 14.46 & 0.00 & 25.02 \\
\hline \multirow{5}{*}{35 days } & $0-2^{\prime}$ & 15.00 & 57.14 & 20.16 & 51.16 \\
\hline & $2-4^{\prime}$ & 12.00 & 42.36 & 12.66 & 36.16 \\
\hline & $4-6^{\prime}$ & 3.86 & 40.16 & 5.16 & 24.32 \\
\hline & $6-8^{\prime}$ & 0.57 & 28.13 & 0.00 & 12.35 \\
\hline & $8-10^{\prime}$ & 0.00 & 07.23 & 0.00 & 13.42 \\
\hline \multirow{5}{*}{42 days } & $0-2^{\prime}$ & 17.29 & 68.54 & 19.75 & 46.16 \\
\hline & $2-4^{\prime}$ & 4.71 & 53.21 & 10.13 & 40.13 \\
\hline & $4-6^{\prime}$ & 0.14 & 32.15 & 10.13 & 32.15 \\
\hline & $6-8^{\prime}$ & 0.00 & 16.35 & 1.88 & 22.12 \\
\hline & $8-10^{\prime}$ & 0.00 & 13.86 & 0.00 & 12.84 \\
\hline \multirow{5}{*}{49 days } & $0-2^{\prime}$ & 12.37 & 56.32 & 17.50 & 53.56 \\
\hline & $2-4^{\prime}$ & 10.50 & 48.34 & 9.00 & 42.58 \\
\hline & $4-6^{\prime}$ & 4.50 & 39.32 & 6.17 & 35.14 \\
\hline & $6-8^{\prime}$ & 0.12 & 45.12 & 1.66 & 28.13 \\
\hline & $8-10^{\prime}$ & 0.00 & 28.35 & 0.00 & 9.56 \\
\hline
\end{tabular}

The results of the present experiment suggest that broilers using nipple drinkers may spend more energy to consume water than those drinking from bell drinkers. It should be noted that young broilers present anatomic limitations (beak size/shape) to drink from nipple drinkers. Moreover, the lower water intake and higher use of energy by broilers drinking from nipple drinkers become even more important under heat stress conditions. These are important considerations when deciding which drinker type to be used in broiler houses. High environmental temperatures cause metabolic changes and trigger physiological 
mechanisms in broilers in order to prevent and to overcome possible homeastasis disturbances, and water is essential to allow birds to dissipate heat and to reestablish thermal homeostasis. Therefore, adequate water supply is critical for broilers under different situations.

\section{CONCLUSION}

The results of the present experiment show that broilers have a well-regulated water intake pattern, which is affected by drinker type and environmental temperature.

\section{REFERENCES}

Barton TL. Relevance of water quality to broiler and turkey performance. Poultry Science 1996; 75:854-856.

Belay T, Bartels KE, Wiernusz CJ, Teeter RG. A detailed colostomy procedure and its application to quantify water and nitrogen balance and urine contribution to thermobalance in broilers exposed to thermoneutral and heat-distressed environments. Poultry Science 1993; 72:106-115.

Belay T, Teeter RG. Broiler water balance and thermobalance during thermoneutral and high ambient temperature exposure. Poultry Science 1993; 72:116-124.

Bruno LDG, Macari M. Ingestão de água: mecanismos regulatórios. In: Macari M, Furlan RL, Gonzales E, editors. Fisiologia aviária aplicada à frangos de corte. Jaboticabal: FUNEP; 2002. p.201-208.

Fernandes LM, Vieira SL, Baptista CB. Development of digestive organs and carcass yield of broilers from diverse genetic origin raised with regular or nipple drinkers. Brazilian Journal of Poultry Science 2002; 4:1-12.

Grizzle JM, Armbrust TA, Bryan MA, Saxton AM. Water quality II: the effect $f$ water nitrate and bacteria on broiler growth performance. Journal of Applied Poultry Research 1997; 6:48-55.

Klosowki ES, Campos AT, Gasparino E, Campos AT, Amaral D. Temperatura da água em bebedouros utilizados em instalações para aves de postura. Engenharia Agrícola 2004; 24:493-500.

Leeson S, Summers JD, editors. Commercial poultry nutrition. Montreal: University Books; 1991. 400 p.

Lott BD. The effect of feed intake on body temperature and water consumption of male broilers during heat exposure. Poultry Science $1991 ; 70: 756-759$.

Lott BD, May JD, Simmons JD, Branton SL. The effect of nipple height on broiler performance. Poultry Science 2001; 80:408-410.

Macari M. editor. Água na avicultura industrial. Jaboticabal: Funep, 1996. 128 p.
Maiorka A, Santin E, Dahlke F, Boleli IC, Furlan RL, Macari M. Posthatching water and feed deprivation affect the gastrointestinal tract and intestinal mucosa development of broiler chicks. Journal of Applied Poultry Research 2003; 12:483-492.

May JD, Lott BD. Feed and water consumption patters of broilers at high environmental temperatures. Poultry Science 1992; 71:331336.

National Research Council. Nutrient requirements of poultry: nutrient requirements of domestic animals. 9th rev. Washington: Ed. Natl. Acad. Press; 1994.

SAS Institute. User's guide: statistics. Cary: Sas Institute; 2000.

Silva JHV, Jordão Filho J, Silva EL, Ribeiro MLG, Furtado DA. Efeito do bebedouro e da densidade de alojamento no desempenho de frangos alojados em alta temperatura. Revista Brasileira de Engenharia Agrícola e Ambiental 2005; 9:636-641.

Vest LR. Management of closed water systems for poultry. Poultry Science 1986; 65 (Suppl.1):139.

Wideman RF, Ford BC, May JD, Lott BD. Acute heat acclimation and kidney function in broilers. Poultry Science 1984; 73:75-88. 